1 Department of Health Policy, London School of Economics, London, UK

2 London School of Hygiene and Tropical Medicine

3 UCL Institute for Global Health

4 Center for Policy Impact in Global Health, Duke Global Health Institute, Duke University

Cite this as: BMJ 2022;376:0196 http://dx.doi.org/10.1136/bmj.0196 Published: 24 January 2022

\section{Parties may lead to his downfall, but is this the worst of what Johnson has done?}

\author{
The parties raise a much bigger issue of accountability and poor pandemic response, argue these \\ authors
}

\author{
Clare Wenham, ${ }^{1}$ Martin McKee, ${ }^{2}$ Rochelle A. Burgess, ${ }^{3}$ Gavin Yamey ${ }^{4}$
}

Sometimes it's the smaller things that end people's careers: Al Capone, who evaded punishment for his years as a mob boss, was put behind bars for tax evasion. With Boris Johnson, UK prime minister, it won't be his role in Brexit and the subsequent damage it caused to the UK's finances and global status. Nor will it be his mishandling of the pandemic, leaving a country which has a world leading health system and research capacity, and which is ranked second of 195 nations for pandemic preparedness, with one of the highest mortality rates from covid-19 in the world. ${ }^{1}$ It appears that what will bring him down are the pictures that contrast him and his staff drinking wine in the garden of 10 Downing Street with the Queen sitting alone at her husband's funeral.

While we can all agree that holding a party in the midst of a pandemic undermines the public trust that underpins support for public health measures, is this the worst of what Boris Johnson has done?

If someone had visited Britain from Mars in 2016 they could easily have concluded that the EU referendum was all about health. They would have seen a bus painted with the message that a vote for Britain to leave the European Union would give an extra £350 million every week to the NHS. Now, of course, we know that Brexit has instead harmed the NHS. The supply of EU health workers on which the NHS has long depended has reduced markedly; major shortages of medicines and medical technology following a large drop in imports from the EU were only avoided by huge efforts by those involved, with more problems looming. ${ }^{2-4}$ And the damage to the economy of leaving the EU will reduce the scope to address the weaknesses in society that left so many people susceptible to the direct and indirect effects of the pandemic. ${ }^{5}$ Looking ahead, the British government's failure to implement what it agreed on Ireland threatens hard won peace and stability that has built up over three decades. But it will not be these problems that lead to Johnson's downfall.

Nor will it be his performance during the pandemic. In fairness, he can hardly be blamed for decisions made when the pandemic began, given that he was largely absent, missing a series of crisis response meetings. ${ }^{6}$ Yet, he will be remembered for presiding over a covid-19 response that offered a poorly implemented test and trace system, and processes that seemed to be about providing opportunities for private companies with no track record of working with the NHS to make profits from supplying sub-standard protective equipment, testing kits, and much else. ${ }^{7}$ The sole criterion for contracts seemed to be having privileged access to VIP lanes that led directly to officials. ${ }^{8}$ The cost was paid by those on the frontline of health and social care and other public facing roles who were denied effective protection, people who were disproportionately drawn from poorer communities and from Black, Asian, or ethnic minority groups.

The consequences of Johnson's government's decisions have contributed substantially to a covid related death toll of over 175 ooo people. This places the UK among the worst performing countries globally. ${ }^{9}$ And the impact on the economy is just as bad. Johnson's attempt to protect the economy has achieved the worst of both worlds, with the UK having the largest contraction of GDP among the G7 countries during the pandemic. ${ }^{10}$

And yet these failings have not been of such concern to MPs as they decide whether to submit letters of no-confidence in him. Instead, the straw that has broken the camel's back has been whether or not Johnson went to a party in Downing Street in May 2020 , whether the party was a party or a work event, and whether he lied to parliament to that effect. This at a time when gatherings of over six people were restricted.

This focus on a technicality has come from the same government who have, at many points over the past two years, appealed to the public to apply "common sense" to the spirit of social distancing requirements. ${ }^{11}$ Johnson argues that "no-one had told him that the party wasn't allowed to go ahead" but it's hard not to feel that he should have known that a gathering wouldn't be in the spirit of things. ${ }^{12}$

Yet, we are hung up on technicalities rather than analysing the bigger picture of what a decade of Conservative leadership has done to the UK's covid-19 response.

Austerity is widely shown to have been disastrous for public health, leading to a slashing of public health budgets, and knock on effects on the health system..$^{13}$ This left the NHS teetering on collapse as the pandemic struck. Moreover, it is the health impact of austerity that increased risk factors for poorer outcomes with covid-19. ${ }^{13} 14$

Moreover, a failure to pay health and social care workers fairly, and attributing real value to their expertise and care, has resulted in fewer workers than we need during the covid pandemic. This crisis in the workforce has been amplified by those who are off work with a combination of covid-19 and stress or exhaustion from working during a pandemic, and 
further compounded by Brexit's limitations on recruiting healthcare workers-notably nurses-from the EU.

On top of this, the desire for the Conservative government to be a haven for biotech development, has contributed to the UK government's decision to favour maintaining pharmaceutical patents, rather than encouraging vaccine production elsewhere in the world through a waiver of intellectual property rights at the World Trade Organisation. ${ }^{15}$ This has meant that global vaccination is lagging, not only putting healthcare workers at risk globally, but facilitating greater spread of disease through insufficient vaccination coverage which increases the risk of new variants emerging.

One could argue that the worst is yet to come. The pandemic has, undeniably, provided a cover for the most significant dismantling of state that the country has experienced in recent years. While the media debated the definition of "parties," policies that are detrimental to health have been pushed through Parliament. The disruption of another reorganisation of the NHS; the legacy of procurement scandals costing billions; policies limiting the capacity of protest against defunding the NHS; exclusionary immigration policies; the list goes on and on. ${ }^{16-18}$ Our obsession with the behaviour of a single man masks a wider system of change that will be hugely detrimental to the future of this country. We should be wise to the ways in which the narrative of crisis creates opportunities for abuses of the system. ${ }^{19}$ This will not end with Johnson; whoever replaces him will likely continue to create a false dichotomy between health and the economy; make public health a platform for division; and ignore the responsibility of government to protect and support all people within their borders. ${ }^{2021}$

But these events raise a much bigger issue of accountability. Many, and in particular families bereaved by covid-19, have been clamouring for an inquiry into what went wrong in the pandemic. It will happen, but we may have to wait years for its findings. For now, all we can hope for is some insight into a very small part of that response: whether the prime minister knew about a party in his own garden. This should be well down the list of priorities. But in the end, it is the answer to that question that seems likely to decide the fate of an entire government.

Competing interests: MMK is a member of Independent SAGE. None further declared.

Provenance and peer review: commissioned, not peer reviewed

1 Yamey G, Wenham C. The U.S. and U.K. Were the Two Best Prepared Nations to Tackle a Pandemic-What Went Wrong? TIME July 2020. https://time.com/5861697/us-uk-failed-coronavirus-response/

2 The Health Foundation. Large drop in the number of new nurses coming from the EU to work in the UK. https://www.health.org.uk/chart/chart-large-drop-in-the-number-of-new-nurses-comingfrom-the-eu-to-work-in-the-uk

3 Dayan M. What happened to those Brexit medicines shortages? September 2021. https://www.nuffieldtrust.org.uk/news-item/what-happened-to-those-brexit-medicines-shortages

4 Dayan M. The impact of Brexit on health is only just beginning. BMJ2021;375:n3119. doi: 10.1136/bmj.n3119. pmid: 34924358

5 Office for Budget Responsibility. Brexit analysis. https://obr.uk/forecasts-in-depth/the-economyforecast/brexit-analysis/

6 The Guardian. Boris Johnson missed five coronavirus Cobra meetings, Michael Gove says https://www.theguardian.com/world/2020/apr/19/michael-gove-fails-to-deny-pm-missed-fivecoronavirus-cobra-meetings

7 National Audit Office. Test and trace in England. https://www.nao.org.uk/report/test-and-tracein-england-progress-update/

8 Siddique H. Use of 'VIP lane' to award Covid PPE contracts unlawful, high court rules https://www.theguardian.com/politics/2022/jan/12/use-of-vip-lane-to-award-covid-ppe-contractsunlawful-high-court-rules

9 John Hopkins University. Coronavirus Resource Center. https://coronavirus.jhu.edu/data/mortality

10 Office for National Statistics. International comparisons of GDP during coronavirus (COVID-19) pandemic. https://www.ons.gov.uk/economy/grossdomesticproductgdp/articles/internationalcomparisonsofgdpduringthecoronaviruscovid19pandemic/2021-02-01
11 The Telegraph. Boris Johnson urges Britons to 'use common sense' as he announces new freedoms from May 17. May 2021. https://www.telegraph.co.uk/global-health/science-and-disease/coronavirus-news-lockdown-rules-may-covid-vaccine-uk-cases/

12 The Independent. Nobody told me drinks event was against rules, says Boris Johnson as MPs plot downfall. https://www.independent.co.uk/news/uk/politics/boris-johnson-party-downingstreet-b1995751.html

13 Stuckler D, Reeves A, Loopstra R, et al. Austerity and health: the impact in the UK and Europe, European Journal of Public Health, Volume 27, Issue suppL_4, October 2017, Pages 18-21, doi: 10.1093/eurpub/ckx167

14 The BMA. Austerity - COVID's little helper. October 2020. https://www.bma.org.uk/news-andopinion/austerity-covid-s-little-helper

15 Nature. New UK science minister takes on ambitious research agenda. September 2021. https://www.nature.com/articles/d41586-021-02609-0

16 Dyer C. Covid-19: Government's use of VIP lane for awarding PPE contracts was unlawful, says judge. BM/2022;376:096. doi: 10.1136/bmj.096. pmid: 35027367

17 The Independent. Government could be forced to draw up new bill after 'draconian' protest laws defeated by Lords https://www.independent.co.uk/news/uk/politics/protest-laws-lords-defeatbill-b1995372.html

18 The Nationality and Borders Bill is racist - we want Government to think again https://goodlaw project.org/news/nationality-borders-bill-clause-9/

19 Vice. Coronavirus Is the Perfect Disaster for 'Disaster Capitalism' https://www.vice.com/en/article/5dmqyk/naomi-klein-interview-on-coronavirus-and-disaster-capitalism-shock-doctrine

20 Oliver D. David Oliver: The false dichotomies in pandemic commentary. BMJ2021;372:m4937. doi: 10.1136/bmj.m4937. pmid: 33408136

21 The BMA. Immediate restriction relaxation is risk to public as NHS still under crippling pressure warns BMA. January 2022. https://www.bma.org.uk/bma-media-centre/immediate-restrictionrelaxation-is-risk-to-public-as-nhs-still-under-crippling-pressure-warns-bma 